\title{
INCENTIVES AND CAREERS IN ORGANIZATIONS
}

\author{
Robert Gibbons
}

NBER Working Paper 5705

\section{NATIONAL BUREAU OF ECONOMIC RESEARCH 1050 Massachusetts Avenue \\ Cambridge, MA 02138 \\ August 1996}

I thank John Abowd, George Baker, James Baron, Henry Farber, Bengt Holmstrom, Lawrence Katz, David Kreps, Edward Lazear, Bentley MacLeod, Margaret Meyer, Kevin J. Murphy, Canice Prendergast, and Michael Waldman for years of discussions of these topics. The Center for Advanced Study in the Behavioral Sciences provided an ideal setting and financial support (through a Fellowship funded in part by NSF grant SBR-9022192). This paper is part of NBER's research program in Labor Studies. Any opinions expressed are those of the author and not those of the National Bureau of Economic Research.

(C) 1996 by Robert Gibbons. All rights reserved. Short sections of text, not to exceed two paragraphs, may be quoted without explicit permission provided that full credit, including $(\mathcal{O}$ notice, is given to the source. 


\title{
INCENTIVES AND CAREERS IN ORGANIZATIONS
}

\begin{abstract}
This paper surveys two related pieces of the labor-economics literature: incentive pay and careers in organizations. In the discussion of incentives, I first summarize theory and evidence related to the classic agency model, which emphasizes the tradeoff between insurance and incentives. I then offer econometric and case-study evidence suggesting that this classic model ignores several crucial issues and sketch new models that begin to analyze these issues. In the discussion of careers in organizations, I begin by summarizing evidence on wages and positions using panel data within firms. This evidence is sparse and far-flung (drawn from industrial relations, organizational behavior, and sociology, as well as from labor economics); I identify ten basic questions that merit more systematic investigation. Turning to theory, I describe building-block models that address one or a few pieces of evidence, but focus on more recent models that address broad patterns of evidence.
\end{abstract}

\section{Robert Gibbons}

Johnson Graduate School of Management

Cornell University

Ithaca, NY 14853

and NBER

Robert_Gibbons@Cornell. EDU 
An outsider might be surprised to learn that modern labor economics has little to say about activities inside firms. After all, isn't work (i.e., what workers do once they go through a firm's doors) one of the field's most natural areas of inquiry?

Let's take stock. Several research areas in labor economics end precisely when an employment relationship begins: unemployment duration and labor-force participation are examples, and even labor demand typically focuses on how many workers should be hired rather than on what the firm should then do with them. Other research areas in labor economics reduce the employment relationship to a wage, or at most a wage profile: on-the-job search, labor supply, and human-capital models of earnings, for example. Even research on the return to seniority more often focuses on econometric issues than on what actually happens during an employment relationship; similarly, research on training more often focuses on pre-employment government-sponsored programs than on skill development in firms. Simply put, modem labor economics contains little work on work.

The situation may be changing. In this paper I describe theory and evidence on two aspects of some employment relationships: incentive pay and careers in organizations. ${ }^{1}$ Most of the theory I describe is recent, emphasizing games and contracts more than the workhorse theories of labor economics in the 1970s and ' 80 s, human capital and search. Much of the evidence is also new, at least in the sense of not having been part of the published discourse in labor economics over the last few decades. This same evidence is also old, however, both in the sense of sometimes referring to events long past (sharecropping in 1910 or a machine shop in Chicago around 1950, for example) and in the sense of sometimes being fairly well-known outside labor economics.

Because there is not much empirical work on employment relationships in labor economics, I draw on other fields-including accounting, human resource management, industrial relations, and organizational sociology-whenever my exposure allows. Unfortunately, data on employment relationships often must be collected virtually by hand. Doing the hard work of data collection and utilizing the microeconometric expertise that has become the hallmark of labor economics are crucial next steps for this emerging literature. In the meantime, I limit discussion of theory to classes of models that seem likely to deliver empirical implications (or, better still, have already done so).

1 Other aspects of employment relationships also deserve attention, such as job design, skill development, and participative decision-making. Research on these issues seems less ready for summary and assessment, but intriguing theory and evidence has begun to emerge: see Milgrom and Roberts (1988), Holmstrom and Milgrom (1991), Itoh (1992), Prendergast (1995), and Meyer, Olsen, and Torsvik (forthcoming) for theory and Osterman (1994, 1995), Pencavel and Craig (1994), and Ichniowski, Shaw, and Prennushi (1995) for evidence. 


\section{Incentive Pay}

There are many senses in which pay may be linked to performance. Perhaps the simplest case is where workers' productivities differ and wages equal marginal products. More often, however, the phrase "pay for performance" connotes the provision of incentives. In this section I discuss the dominant model of incentive contracting, the principal-agent model. ${ }^{2}$

Several of the main issues can be illustrated quite simply in the context of sharecropping. Three standard sharecropping contracts are: wage labor, which imposes no risk on the agent; crop sharing, which shares risk between the principal and the agent; and fixed-payment land rental, which leaves the agent with all the crop risk. The classic agency model, which emphasizes the tradeoff between incentives and insurance, implies that where there is greater crop risk there should also be more risk-sharing-more used of fixed wages and crop sharing rather than land rental. Higgs (1973) presents evidence consistent with this prediction: for both cotton and corn, and for two empirical measures of risk, a cross-sectional analysis of the southern states of the US for 1910 finds more risk-sharing in states with greater crop risk. But Alston and Higgs (1982) document that Higgs's comforting finding obscures both (1) enormous variation within each of these three main classes of contracts and (2) significant variation across the three classes of contracts even after controlling for risk.

Both the organization and the spirit of this section parallel this research on sharecropping. Parallel to Higgs's paper, I begin by summarizing the theory and evidence on the classic agency model. Parallel to Alston and Higgs's paper, I then explore five new issues, in the hope of accounting for some of the enormous richness in incentive contracting that the classic agency model simply chalks up as unexplained variation. I conclude that risk is a significant issue in incentive contracting, but that the principal-agent literature's initial obsession with its consequences distracted us from a host of equally important issues.

\section{A. The Much-Studied Tradeoff between Incentives and Insurance}

The classic model in agency theory involves an agent who takes an action (a) to produce output of value $y$. The principal owns the output but contracts to share it with the agent by paying a wage contingent on output, $w(y)$. There is noise in the production function, so the agent's output is uncertain. Furthermore, the agent is risk-averse. Paying a constant wage, independent

2 For lack of space, I ignore two smaller literatures on incentives: efficiency-wage and deferred-payment models, which differ from the principal-agent model in that wages do not vary with performance. In an efficiency-wage model, a firm pays a high wage to all workers but subsequently fires those whose performance is too low; see Shapiro and Stiglitz (1984) for theory and Capelli and Chauvin (1991), Krueger (1991), and Abowd, Kramarz, and Margolis (1994) for evidence. In a deferred-payment model, workers are again fired for poor performance, but now 
of $y$, would provide the agent with full insurance but no incentive; selling the agent the firm for a fee of $F$ (or, equivalently, paying the agent $w(y)=y-F$ ) would provide the agent with full incentives but no insurance.

An intuitive closed-form solution can be derived in the linear-normal-exponential case. The production function is linear, $y=a+\varepsilon$, where $\varepsilon$ is a normally distributed noise term with zero mean and variance $\sigma^{2}$. The incentive contract is linear, $w(y)=s+b y$, where the intercept $s$ is the salary and the slope $b$ is the bonus rate. The agent's utility function is $U(x)=-e^{-r x}$, where $r$ $>0$ is the agent's coefficient of absolute risk aversion and $x=w-c(a)$ is the agent's net payoffthe realized wage minus the convex disutility of action $c(a)$. The principal is risk-neutral and so seeks to maximize the expected value of profit, $y-w$.

Given a contract $w(y)=s+$ by, the agent's problem is to choose an action to maximize the expected utility

$$
\int_{\varepsilon} e^{-r[s+b(a+\varepsilon)-c(a)]} \phi(\varepsilon) d \varepsilon=-e^{-r[s+b a-c(a)]} \int_{\varepsilon} e^{-r b \varepsilon} \phi(\varepsilon) d \varepsilon
$$

where $\phi(\varepsilon)$ denotes the normal density function. The agent's optimal action, denoted $a^{*}(b)$, solves $c^{\prime}(a)=b$. The agent's maximized expected utility is therefore

$$
-e^{-r\left[s+b a^{*}(b)-c\left[a^{*}(b)\right]\right\}} \int_{\varepsilon} e^{-r b \varepsilon} \phi(\varepsilon) d \varepsilon=-e^{-r\left[s+b a^{*}(b)-c\left[a^{*}(b)\right]-(1 / 2) r b^{2} \sigma^{2}\right]},
$$

so the agent's certainty equivalent is

$$
C E(s, b)=s+b a^{*}(b)-c\left[a^{*}(b)\right]-\frac{1}{2} r b^{2} \sigma^{2}
$$

That is, the agent's certainty equivalent from the contract $w(y)=s+$ by is the expected wage minus the cost of effort minus the cost of bearing risk. The principal's expected profit is

$$
E \Pi(s, b)=(1-b) a^{*}(b)-s
$$

so the total surplus (i.e., the sum of the principal's expected profit and the agent's certainty equivalent) depends on $b$ but not on $s$ :

$$
C E(s, b)+E \Pi(s, b)=a^{*}(b)-c\left[a^{*}(b)\right]-\frac{1}{2} r b^{2} \sigma^{2}=T S(b) .
$$

We can now determine the efficient contract slope, denoted $b^{*}$ : it is the slope that maximizes the total surplus TS(b). If the parties agreed to a contract with some other slope then

forfeit higher wages later in their career (or after retirement, through a pension); see Lazear (1979) for theory and Goldin (1986), Hutchens (1987), and Margolis (1995) for evidence. 
both parties could be made better off by switching to a contract with slope $b^{*}$ and choosing an appropriate value of $s$ to distribute the increased total surplus. The first-order condition for $b^{*}$ is $a^{* \prime}-c^{\prime} a^{* \prime}-r b \sigma^{2}=0$. Because $c^{\prime}\left[a^{*}(b)\right]=b$, we have $a^{* \prime}=1 / c^{\prime \prime}$ and hence

$$
b^{*}=\frac{1}{1+r \sigma^{2} c^{\prime \prime}} \text {. }
$$

This result makes sense. Since $r, \sigma^{2}$, and $c^{\prime \prime}$ are positive, $b^{*}$ is between zero (full insurance) and one (full incentives). Furthermore, $b^{*}$ is smaller if the agent is more risk-averse ( $r$ is higher) or there is more uncertainty in production ( $\sigma^{2}$ is higher) or marginal disutility increases more quickly $\left(c^{\prime \prime}\right.$ is higher).

This solution to the classic model is tidy but flawed: Mirlees (1974) showed that the best linear contract, $w=s+b^{*} y$, is inferior to various non-linear contracts. In particular, a stepfunction contract (where the agent earns $\mathrm{w}_{\mathrm{H}}$ if $\mathrm{y} \geq \mathrm{y}_{0}$ but $\mathrm{w}_{\mathrm{L}}<\mathrm{w}_{\mathrm{II}}$ if $\mathrm{y}<\mathrm{y}_{0}$ ) can perform very well, approaching the twin goals of full incentives and full insurance in the limit (as $y_{0}$ and $w_{L}$ decrease in appropriate fashion, so that the agent almost surely receives $\mathrm{w}_{\mathrm{H}}$ and yet has incentives from fear of $w_{L}$ ). Mirrlees's result prompted a decade of research on how the optimal contract depends on the details of the utility function and the conditional distribution of output given the agent's action. In brief, this work showed that the optimal contract in the classic agency model is extremely sensitive to these details. In particular, the optimal contract is linear only under very special assumptions about the utility function and the conditional distribution of output.

Holmstrom and Milgrom (1987) reinterpreted the classic agency model so as to rescue linear contracts. Rather than a single action (a) that influences a single outcome (y), Holmstrom and Milgrom envision a sequence of actions (say, one per day, over the course of a year) influencing a corresponding sequence of outcomes. There are no connections across days (i.e., the action a on day $t$ affects that day's outcome, $y_{1}$, but has no influence on any other day's outcome) and all past outcomes are observed before the next day's action is chosen. The output $y$ from the classic model is interpreted as the aggregate output for the year in the sequential-action model: $\mathrm{y}=\Sigma \mathrm{y}_{\mathrm{l}}$.

Suppose that each day's outcome takes one of two values-say $\mathrm{L}$ or $\mathrm{H}$. Then a one-day incentive contract is simply a pair of wages: $w_{H}$ is paid if the outcome is $H$; $w_{L}$ if $L$. Suppose that the agent labors under the same one-day contract for all the days of the year. If there are $T$ days in the year and the agent produces $\mathrm{H}$ on $\mathrm{N}$ of these days then the aggregate output for the year is $y=T L+N(H-L)$ and the aggregate wage for the year is $w=T w_{L}+N\left(w_{I}-w_{L}\right)$. Thus, $N=(y-$ $\mathrm{TL}) /(\mathrm{H}-\mathrm{L})$ and

$$
w=\frac{T\left(H w_{L}-L w_{H}\right)}{H-L}+\frac{w_{H}-w_{L}}{H-L} y=s+b y .
$$


That is, if the agent labors under the same one-day contract throughout the year then the aggregate wage is a linear function of the aggregate output. Given several other assumptions, Holmstrom and Milgrom show not only that it is optimal for the agent to labor under a constant one-day contract but also that the optimal slope in the aggregate representation of this contract (i.e., $\mathrm{w}=\mathrm{s}+$ by) is $\mathrm{b}^{*}$, just as in the classic agency model.

In my view, the main contribution of this Holmstrom-Milgrom model is not that it justifies linear contracts (by imposing quite strong assumptions), but rather that it alerts us to gaming as a natural consequence of non-linearity. For example, a step-function contract of the kind studied by Mirrlees (in the classic one-action model) induces no effort once the agent's aggregate output to date passes the hurdle $y_{0}$ (in the daily-action model). More generally, if the incentive contract for the year is a non-linear function of year-end aggregate output then the worker's incentives change from day to day, depending on the aggregate output to date. A growing body of evidence is consistent with this prediction: see Healy (1985) on bonus plans with ceilings and floors, Asch (1990) and Oyer (1995) on bonuses tied to quotas, Chevalier and Ellison (1995) on the effects of even modest convexities in smooth pay plans, and Ehrenberg and Bognanno (1990) on performance across rounds in professional golf tournaments. ${ }^{3}$

There is other evidence more closely related to the classic agency model. One basic question is "Does pay vary with performance?" For example, by the early 1980s, the received wisdom was that the compensation of chief executive officers (CEOs) in large US firms was closely related to the firm's size but unrelated (or even negatively related!) to its stock-market performance. Murphy (1985) noted, however, that if big firms pay higher salaries but small firms have superior stock-market performance (the "small-firm effect" from finance) then a cross-section regression of cash compensation (salary plus bonus) on stock-market performance will be biased downwards, unless there are adequate controls for firm heterogeneity. Murphy found that including fixed effects in a panel-data model produces a strong statistical relationship between CEO pay and stock-market performance. ${ }^{4}$

A second basic question is "Do incentives matter?" In brief, the answer is "Yes." For example, the evidence summarized above on the effects of non-linear incentive plans motivates this conclusion. Others have studied the proposition that steeper slopes create stronger incentives:

3 Incentive contracts obviously exist outside as well as inside employment relationships, golf toumaments being just one example. In trying to understand incentive contracts inside firms, I will sometimes draw on examples from outside. Much work remains to be done on how incentive contracts differ (by choice or by constraint) depending on whether they are inside or outside firms; see Holmstrom and Milgrom (1991) and Baker, Gibbons, and Murphy (1996) for initial explorations of this issue.

4 Jensen and Murphy (1990) estimate that the pay-for-performance slope for the CEO of a typical large US firm is at most $b=.003$. Jensen and Murphy argue that such a pay-for-performance relation is statistically but not economically significant, whereas Haubrich (1994) argues that plausible parameter values in the classic agency model can yield an efficient slope of this magnitude. 
$a^{*}$ (b) increases with b. Lazear (1996), for example, finds that the output of workers installing automobile windshields increased after a switch from hourly wages to piece rates. ${ }^{5}$ Abowd (1990) and Kahn and Sherer (1990) estimate the sensitivity of managerial pay to current performance and then estimate the effect of this sensitivity on subsequent performance. ${ }^{6}$ The results are generally consistent with the theory but are somewhat noisy, in keeping with having to estimate rather than observe the relation between pay and performance. Gaynor and Gertler (1995) use data on medical partnerships, where the sharing rule is included in the data but was chosen by the partners. Their instrumental-variable estimates again are consistent with the simple proposition that incentives matter. Finally, there is evidence that investors believe that incentives matter: Brickley, Bhagat, and Lease (1985) find that there is a significant increase in a firm's stock price (net of any movement in the market as a whole) when the firm announces a stockbased compensation plan; Tehranian and Waegelein (1985) present analogous evidence for announcements of accounting-based bonus contracts.

There is also evidence related to the main idea behind the classic agency model-the tradeoff between incentives and insurance. For example, there is evidence that the slope falls as risk or risk-aversion increases. As noted earlier, Higgs (1973) presents evidence from sharecropping in 1910 that the slope falls as risk increases; Garen (1994) offers similar evidence for CEOs of large US firms. Gaynor and Gertler (1995) find that the slope of the sharing rule in medical partnerships falls as the partners' risk-aversion increases.

The tradeoff between insurance and incentives produces further predictions in a richer model with multiple performance measures, as follows. Suppose there is a second performance measure, $\mathrm{z}=\mathrm{a}+\mu$, where $\mu$ is a normally distributed noise term possibly correlated with $\varepsilon$. (Theoretical and empirical work in accounting often interprets $y$ as the change in the firm's stockmarket value and $\mathrm{z}$ as the firm's accounting earnings, but many other interpretations are possible.) Consider the contract $w=s+$ by $+d z$. Holmstrom (1979) shows that the optimal contract uses both performance measures (i.e., $\mathrm{b}^{*} \neq 0$ and $\mathrm{d}^{*} \neq 0$ ) unless one is a sufficient

5 Even this seemingly simple comparison raises several issues. First, output was not zero before the imposition of piece rates, suggesting that monitoring and/or efficiency wages should be included in the theoretical and empirical analyses. Second, as Lazear (1986a) and Brown (1992) analyze, high-productivity workers may prefer piece rates to salaries, so the switch to piece rates may change the composition of the workforce; fortunately, Lazear (1996) has data on individual workers over time. Third, and perhaps most important, many piece-rate plans eventually run afoul of the "ratchet effect" described in the next sub-section.

6 Because the agent's action is unobservable, empirical work cannot directly test whether $a^{*}(b)$ increases with $b$, and so relies on either performance $(y)$ or profit $(\pi=y-w)$ as a proxy for the agent's action. Lazear uses performance; Abowd uses various forms of profit; and Kahn and Sherer use numerical performance ratings awardod by supervisors (which are more like y than like $\pi$, provided that supervisors are not judging performance relative to wages). The distinction between performance and profit affects the interpretation of the evidence. If observations on $b$ were randomly sprinkled near $b^{*}$ (say, due to small mistakes) then $a^{*}(b)$ would increase with $b$, so $E(y)$ would increase with $b$, but $E(\pi)$ would be locally constant, because TS(b) is maximized at $b^{*}$. On the other hand, if variations in $b$ were due to (say) unmeasured variation in risk or risk-aversion then both $E(y)$ and $E(\pi)$ would increase in $\mathbf{b}$. 
statistic for the other. That is, $\mathrm{d}^{*}=0$ only if $\mathrm{z}$ contains no additional information about the agent's action beyond what is contained in $\mathrm{y}$ (i.e., $\mathrm{z}=\mathrm{y}+\phi$, or $\mu=\varepsilon+\phi$, where $\phi$ is independent of $\varepsilon$ ); likewise, $b^{*}=0$ only if y contains no additional information beyond $z$ (i.e., $y$ $=z+\phi$, or $\varepsilon=\mu+\phi$, where $\phi$ is independent of $\mu$ ). In Holmstrom's model, therefore, performance measures are simply signals about the agent's action, and a signal is not useful if it conveys no incremental information.

Some performance measures come from outside the firm, such as from other firms in the same industry. Consider $\mathrm{n}$ firms, each subject to a common shock $(\theta)$ and an idiosyncratic shock $\left(\varepsilon_{i}\right)$. Suppose $y_{i}=a_{i}+\theta+\varepsilon_{i}$, where $\left(\theta, \varepsilon_{1}, \ldots, \varepsilon_{n}\right)$ are independent normal noise terms. Let $z_{i}$ denote the average of the $n-1$ other firms' outputs $\left(y_{j}\right)$. Then the pure own-performance contract $w_{i}=s+b y_{i}$ subjects the agent to two noise terms, $\theta$ and $\varepsilon_{i}$, whereas the pure relativeperformance contract $w_{i}=s+b\left(y_{i}-z_{i}\right)$ eliminates $\theta$ but subjects the agent to $\varepsilon_{i}$ and to the average of the $n-1$ other idiosyncratic error terms $\left(\varepsilon_{j}\right)$. Holmstrom (1982a) shows that the efficient contract is $w_{i}=s+b y_{i}-d z_{i}$, where $b^{*}>d^{*}>0$. That is, the efficient contract reflects a tradeoff between eliminating the risk from $\theta$ (through the pure relative-performance contract) and avoiding the risk from the average of the $n-1$ other error terms (through a pure own-performance contract). If the variance of $\theta$ is small then it is not worth introducing the risk from the $n-1$ other error terms so $d^{*}$ is close to zero; if the variance of $\theta$ is large then it is important that the contract filter out $\theta$, even at the cost of introducing risk from the other error terms, so $\mathrm{d}^{*}$ is close to $\mathrm{b}^{*}$.

Antle and Smith (1986) look for evidence of relative performance evaluation in CEO pay. Using data on 39 firms in three 2-digit industries, they find weak support for the theory, even though they carefully compute the correlation in "output" for each pair of firms. Gibbons and Murphy (1990) use a less-sophisticated approach but a much larger dataset, including data on pay and performance from 1000 firms, with performance comparisons computed from data on 11,000 firms. Gibbons and Murphy find stronger support for the theory: CEO pay depends on the firm's stock-market performance relative to the market as a whole and (additionally) on the firm's stock-market performance relative to its 1-digit industry. Janakiraman, Lambert, and Larcker (1992) estimate separate regressions for each of 554 firms (as opposed to the pooled regression in Gibbons and Murphy). The mean of the firm-specific estimates in Janakiraman, Lambert, and Larcker is similar to the pooled coefficient in Gibbons and Murphy. ${ }^{7}$

7 Antle-Smith, Gibbons-Murphy, and Janakiraman-Lambert-Larcker also examine the effect of accounting eamings on CEO pay, again relative to the market as a whole and the firm's industry. They all find little evidence of relative performance evaluation involving accounting earnings. Sloan (1993) suggests why, by showing that market-wide movements in earnings are not a major source of noise in earnings. Sloan also finds that eamings are closely correlated with the firm's stock-market performance relative to the market as a whole. That is, an ownperformance contract based on the firm's earnings could have the effect of a relative-performance contract based on own and market stock movements. 
In sum, there is a large body of theory and evidence related to the classic agency model. The theory has developed several insights, such as the role of linear contracts in deterring gaming and the interpretation of performance measures as signals of the agent's action. The evidence is broadly consistent with both the basic theory and its extension to multiple performance measures. But the literature does not explain (or even hint at) why paying for performance is so problematic for many firms.

\section{B. Complications in Real Incentive Contracts}

The main idea behind the classic agency model is that there is a tradeoff between incentives and insurance, but the most striking single fact about real attempts to tie pay to performance is that it is a tricky business. The following examples are all too typical:

At the H.J. Heinz Company, division managers received bonuses only if earnings increased from the prior year. The managers delivered consistent earnings growth by manipulating the timing of shipments to customers and by prepaying for services not yet received, both at some cost to the firm (Post and Goodpaster, 1981). At Bausch \& Lomb, the hurdle for a bonus was higher, often entailing double-digit earnings growth. Again, managers met their targets in ways that were not obviously in the best long-run interest of the firm (e.g., over half a million pairs of "sold" sunglasses were discovered in a warehouse in Hong Kong; Maremont, 1995). At Dun \& Bradstreet, salespeople earned no commission unless the customer bought a larger subscription to the firm's credit-report services than in the previous year. In 1989, the company faced millions of dollars in lawsuits following charges that its salespeople deceived customers into buying larger subscriptions by fraudulently overstating their historical usage (Roberts, 1989). In 1992, Sears abolished the commission plan in its auto-repair shops, which paid mechanics based on the profits from repairs authorized by customers. Mechanics misled customers into authorizing unnecessary repairs, leading California officials to prepare to close Sears' auto-repair business statewide (Patterson, 1992).

In brief, "business history is littered with firms that got what they paid for" (Baker, Gibbons, and Murphy, 1994: 1125). ${ }^{8}$

8 Firms are not the only ones who get what they pay for-governments do, too. Anderson, Burkhauser, and Raymond (1993) offer evidence of cream-skimming in the Job Training Partnership Act (JTPA): the program's goals are to reduce an individual's unemployment and increase the individual's earnings, but program operators are paid based on the measured unemployment and earnings of program participants, so operators have an incentive to enroll participants who would have had short unemployment and high eamings without training. Using cross-state variation in incentive intensity, Cragg (1995) finds that cream-skimming increases when incentives are stronger, but so do the outcomes that the program is intended to induce-reduced unemployment and increased earnings conditional on the characteristics of those enrolled. 
I find it hard to relate the classic agency model to this evidence (and the larger body of evidence it represents). First, much of the evidence concerns non-linear contracts, whereas the classic model began with (and has recently returned to) linear contracts. Second, I see no necessary role for risk-aversion in this evidence, whereas in the classic model the only reason to limit incentives is to provide insurance. Third, and most important, the performance measures used in these real incentive contracts differ from those envisioned in the classic model, as I describe below. In this sub-section, therefore, I abandon the classic model, turning instead to five other issues in incentive contracting-performance measurement, implicit contracts, labor mobility, the ratchet effect, and career concerns. To emphasize that these five issues are departures from the classic model, I assume throughout this sub-section that the agent is riskneutral. For lack of space, I give only brief attention to labor mobility, the ratchet effect, and career concerns; I focus on performance measurement and implicit contracts because I believe that together they offer an important complement to the classic agency model.

1) Performance Measurement: I lack the information to assess whether the incentive plans at Heinz, Bausch \& Lomb, Dun \& Bradstreet, and Sears were mistakes (as opposed to best responses to tough environments), but some of my colleagues in organizational behavior (OB) are less reticent. Kerr's (1975) classic title conveys his field's judgment: "On the Folly of Rewarding A, While Hoping for B." Kerr's paper is so well known in OB that it has earned a place in the canonical MBA core course on organizations; in economics, in contrast, until recently there was no model that could even express Kerr's idea, not to mention evaluate or extend it.

Fortunately, Holmstrom and Milgrom (1991) and Baker (1992) now offer simple models of such distortionary performance measurement. Both emphasize the distinction between the agent's total contribution to firm value (henceforth denoted y) and the agent's measured performance (henceforth p). Even well-informed insiders may find it extremely difficult to assess an agent's total contribution to firm value, because total contribution includes aspects of performance such as the effects of the agent's actions on co-workers and the long-run effects of the agent's current actions. Furthermore, to enforce a contract contingent on the agent's total contribution, the parties would have to specify ex ante how y is to be measured ex post (so that a court would know what to measure if called in to enforce the contract).

These difficulties are assumed away in the classic agency model: the agent's total contribution is called "output," as though it could simply be counted at the end of the contract period, and contracts such as $w=s+$ by are assumed to be trivial to write and enforce. The classic model may capture some employment relationships, where there are few interactions among co-workers and few long-run effects of current actions. Lazear's (1996) study of piece rates paid to workers installing auto windshields may be one example; more generally, Brown 
(1990) finds that piece rates are more likely to be used in jobs with a narrow set of routines than in jobs with a variety of duties.

In a vast array of jobs, however, the Holmstrom-Milgrom and Baker distinction between total contribution and measured performance seems crucially important. For example, Eccles and Crane (1988) describe how investment banks deliver a substantial fraction of a trader's compensation through a subjectively determined bonus, even though many objective aspects of the individual's performance are easily measured on a daily basis. Similarly, Burtis and Gabarro (1995) offer a fictitious but persuasive account of the difficulties of performance evaluation in a law firm: nine objective measures paint a narrow and distorted picture (even when combined with four subjective assessments). Evaluating the performance of almost any manager or professional worker seems likely to involve similar issues - for example, see Greene and Schlesinger (1992) on incentive pay in a cable television firm. Finally, the recent enthusiasm for empowerment, participation, and self-managed teams suggests that difficulties in performance evaluation may become increasingly important for non-managerial workers as well.

Baker models the worker's contribution to firm value as $y=\theta a+\varepsilon$, whereas measured performance is $p=\mu a+v$. As in the classic model, $\varepsilon$ and $v$ are noise terms (independent of $\theta, \mu$, and each other), but $\theta$ and $\mu$ are features of the environment that are privately observed by the worker before choosing an action. As motivated above, Baker assumes that a contract contingent on y cannot be enforced, so the firm is reduced to contracting on p, through the linear contract w $=\mathrm{s}+\mathrm{bp}$. Because the agent's utility, $\mathrm{w}-\mathrm{c}(\mathrm{a})$, depends on $\mathrm{p}$, the agent will be induced to take large actions when $\mathrm{dp} / \mathrm{da}$ (i.e., $\mu$ ) is large; because the firm's profit, $\mathrm{y}$ - w, depends importantly on $\mathrm{y}$, the firm will value large actions when $\mathrm{dy} / \mathrm{da}($ i.e., $\theta)$ is large. Hence Baker's central insight: a good performance measure induces the agent to do the right thing at the right time (i.e., to work hard when doing so is valuable to the firm), so the quality of a performance measure depends on the correlation between $\mathrm{dp} / \mathrm{da}$ and $\mathrm{dy} / \mathrm{da}$. Thus, whereas the classic model views a performance measure as a signal of the agent's action, Baker focuses on the value of the actions that a contract based on the performance measure will induce.

When measured performance omits important dimensions of total contribution, firms understand that they will "get what they pay for," and so may choose weak incentives in preference to strong but frequently dysfunctional incentives. In Kerr's terms, the HolmstromMilgrom and Baker models explore environments in which it might be necessary to reward A while hoping for $\mathrm{B}$, but these models caution against over-rewarding A.?

9 Lazear (1989), Gibbons and Murphy (1990), and Dye (1992) issue similar cautions regarding unbridled use of relative performance evaluation: managers have incentives to choose a reference group they can beat, rather than one that offers high returns; similarly, within a firm, managers have incentives to sabotage the performances of co-workers as well as to improve their own performances. 
2) Implicit Contracts: A worker's total contribution to firm value may be impossible for a court to measure using a method specified ex ante, but well-informed insiders may nonetheless agree ex post on a particular worker's contribution (or at least on an estimate of this contribution). The great advantage of such ex post settling up is that the parties can take into account events that occurred during the contract period that were not foreseen (or were not articulated) ex ante. Thus, it might be possible for the worker and the firm to use an "implicit" contract (i.e., an understanding backed by the parties' reputations instead of law) based on total contribution (y) rather than an "explicit" contract backed by a court but based on distortionary performance measures (p). For example, the firm might promise to pay a bonus if the worker's total contribution exceeds a critical level. The problem is that the firm will be tempted to renege, pocketing the worker's contribution and saving the bonus.

Bull (1987) and MacLeod and Malcomson (1989) model such implicit contracts as repeated-game equilibria. In these models, the firm chooses not to renege only if the present value of the ongoing relationship outweighs the immediate gain from reneging. For example, suppose that y can be either $\mathrm{L}$ or $\mathrm{H}$, and suppose that the firm pays a salary of $\mathrm{S}$ at the beginning of the period and promises to pay a bonus of $\mathrm{B}$ at the end of the period if $\mathrm{y}=\mathrm{H}$. If the worker believes that the firm will keep its promise then the prospect of the bonus induces an optimal action $a^{*}(B)$ from the worker, which in turn determines the firm's expected profit per period from keeping its promise, $\mathrm{E} \pi(\mathrm{S}, \mathrm{B})$.

Suppose that the worker will leave the firm if the firm reneges on a bonus. (Stewart's (1993) account of the rupture of the subjective bonus plan at the investment bank First Boston suggests how difficult it is for a firm to regain its workers' trust after it is perceived to have reneged on an implicit contract.) If the worker produces $y=H$ then the firm can either pay the bonus, resulting in a payoff of $\mathrm{H}-\mathrm{S}-\mathrm{B}$ this period and a payoff of $\mathrm{E} \pi(\mathrm{S}, \mathrm{B})$ in all future periods, or renege on the bonus, resulting in a payoff of $\mathrm{H}$ - $\mathrm{S}$ this period but the loss of the worker thereafter. For simplicity, normalize the firm's payoff after reneging to zero, perhaps from employing a new worker at a wage equal to productivity. Then, given an interest rate $r$, the present value from paying the bonus exceeds the present value from reneging if

$$
H-S-B+\frac{1}{r} E \Pi(S, B) \geq H-S+\frac{1}{r} \cdot 0
$$

or $\mathrm{E} \pi(\mathrm{S}, \mathrm{B}) \geq \mathrm{rB}$. Thus, a decrease in the profitability of the ongoing relationship may wreck an implicit contract; the collapse of the junk bond market may have been just such a precipitating event at First Boston.

Some firms use both explicit and implicit contracts. Lincoln Electric, for example, is well-known for its use of piece rates, but about half of a worker's compensation rides on a subjectively determined bonus (Fast and Berg, 1975). Baker, Gibbons, and Murphy (1994) 
explore the simultaneous use of explicit contracts based on distortionary performance measures (e.g., $\mathrm{w}=\mathrm{s}+\mathrm{bp}$ ) and implicit contracts based on total contribution (e.g., $\mathrm{W}=\mathrm{S}+\mathrm{By}$, so that total compensation is $w+W$ ). One role of the explicit contract is to reduce the size of the implicit-contract bonus that the firm could save by reneging; one role of the implicit contract is to reduce the distortionary incentives created by the explicit contract. Baker, Gibbons, and Murphy show that, under one set of circumstances, the two types of contract are complementary: if the performance measure (p) becomes less distortionary (i.e., if the correlation between $\mathrm{dp} / \mathrm{da}$ and $\mathrm{dy} / \mathrm{da}$ increases) then the explicit contract increases the profitability of the ongoing relationship, thereby making it credible for the firm to promise a larger bonus in the implicit contract. Under the opposite circumstances, explicit contracts hinder implicit contracts: if the explicit contract alone is sufficiently effective then the firm's payoff after reneging is not zero but rather the payoff from using the optimal explicit contract alone; as this payoff increases, it becomes more tempting for the firm to renege on an implicit contract, reducing the bonus the firm can credibly promise.

3) Labor Mobility: One of the fundamental assumptions in labor economics is that workers cannot be bound to firms. That is, firms may provide financial inducements for workers to stay, but a contract stipulating that a worker must stay would not be upheld by a court (at least in the US and similar settings). This assumption pervades the literature on wage determination, from Becker's (1962) analysis of general-purpose human capital to Harris and Holmstrom's (1982) and Beaudry and DiNardo's (1991) analyses of incomplete insurance. The classic agency model, on the other hand, makes the opposite assumption: once the worker has been induced to sign the incentive contract, its eventual consequences can be enforced on the worker. The following evidence from sharecropping suggests that labor mobility may be quite important in incentive contracting, especially if one adopts the Holmstrom-Milgrom sequential-action reinterpretation of the classic agency model.

Recall that Higgs (1973) found that states with higher crop risk have less risk-sharing in their sharecropping contracts (i.e., more wage labor and less crop sharing and fixed-payment land rental), but that Alston and Higgs (1982) found significant variation across the three classes of contract even after controlling for risk. Alston and Higgs argue that one important source of this variation is the prospect of labor mobility. For example, during harvests when the price of cotton was high, bidding wars for labor ensued. Hands paid as wage laborers had no incentive to ignore tempting offers to move, whereas hands paid with crop sharing and hands renting the land would forego their crop if they moved. Thus, in settings where risk considerations alone would imply that wage labor is optimal, the addition of enforcement considerations might make crop sharing efficient. (Crop sharing thus functions like a "hostage" in Williamson's (1983) analysis.) Consistent with this argument, Alston (1981) finds that, holding risk and other factors 
constant, farmers closer to urban areas (i.e., sources of temporary labor that reduce the likelihood and the effect of bidding wars) use wage labor more than either form of risk-sharing.

4) The ratchet effect: Lincoln Electric is well-known for its piece rates because it has avoided both the infamous ratchet effect (where the firm reduces the piece rate if it learns that the job can be done more easily than was at first thought) and its repercussion, output restriction (where workers anticipate that the firm will ratchet the rate and so work slowly to prevent the firm from disceming the true pace at which the job could be done). A large body of evidence suggests that Lincoln is a rare exception. Clawson (1980:170) summarizes many case studies and concludes that "employers insisted that they would never cut a price once it was set, yet every employer did cut prices," Mathewson (1931) offers a huge collection of vignettes concerning output restriction, and Roy (1952) gives detailed evidence of carefully restricted productivity in a machine shop.

To explore these qualitative accounts analytically, it seems natural to consider an environment in which the workers have private information about the job's difficulty and a worker's effort cannot be monitored. In a two-period model of such an environment, Gibbons (1987) shows that if neither the firm nor the worker can commit across periods (i.e., the firm cannot commit in the first period to the second-period piece rate and the worker cannot commit in the first period to remain with the firm for the second period) then both the ratchet effect and output restriction are unavoidable: there is no equilibrium compensation scheme that induces efficient effort.

Kanemoto and MacLeod (1991) and Carmichael and MacLeod (1993) study environments that allow firms to avoid the ratchet effect (and so avoid output restriction as well). Kanemoto and MacLeod analyze a two-period model where the worker's output conveys information about the worker's ability, rather than about the job's difficulty as in Gibbons. In the Kanemoto-MacLeod model, competition for the worker's services from the market of prospective employers gives the worker confidence that the firm will match the market in the second period. Carmichael and MacLeod explore a repeated-game (rather than a two-period) model in which the future value of the ongoing relationship may allow the firm to commit. For example, they describe mutual-monitoring arrangements among British cotton spinners in the 19 th century in which piece rates were publicly posted and sanctions were administered (by other firms!) against firms that cut rates.

5) Career Concerns: When a worker's current performance affects the market's belief about the worker's ability, and hence the worker's future compensation, we say that the worker has current incentives from "career concerns." Fama (1980) suggested that career concerns could eliminate the need for managerial incentive contracts, but Holmstrom (1982b) showed that, in the absence of contracts, career concerns produce an inefficient (but intuitive) pattern of effort over 
time: managers typically work too hard in early years (while the market is still assessing the manager's ability and the manager has a long time to reap the rewards of improving the market's belief) and not hard enough in later years (when the market's belief is hard to budge and the manager has little time to go).

Gibbons and Murphy (1992) add incentive contracts (like those in the classic agency model) to the Fama-Holmstrom model. Because career-concern incentives decline as the manager approaches retirement, the slope of the optimal incentive contract increases, keeping total incentives (roughly) constant. Gibbons and Murphy present evidence on CEO compensation consistent with this prediction. Gompers and Lemer (1994) offer similar evidence for venture capitalists.

\section{New Dimensions}

I have so far tried to make two points. First, risk matters in incentive contracting, but focusing on risk alone yields a sterile perspective. Second, several promising new classes of models have been developed recently, emphasizing aspects of real incentive contracting that are orthogonal to the tradeoff between insurance and incentives. To conclude this section I briefly consider three new issues: motivation, social comparison, and groups.

Baron (1988:494) describes the imagery of workers in economic models of pay for performance as "somewhat akin to Newton's first law of motion: employees remain in a state of rest unless compelled to change that state by a stronger force impressed upon them-namely, an optimal labor contract." Many psychologists subscribe to another view, based on the distinction (and interaction) between intrinsic and extrinsic motivation. Staw (1977) considers two extreme cases: insufficient justification (i.e., low intrinsic rewards, say from a dull task, and no extrinsic rewards) and oversufficient justification (i.e., high intrinsic rewards, say from an interesting task, and high extrinsic rewards). Staw argues that those who choose to perform a task in the insufficient-justification condition may come to believe that the task is interesting, in order to justify their behavior to themselves, whereas those in the oversufficient-justification condition may mistakenly infer that continued participation is motivated by high extrinsic rewards and so come to believe that the task is not interesting.

As a test of the insufficient-justification hypothesis, Staw (1974) measured the attitudes and the performance of Reserve Officer Training Corps (ROTC) cadets both before and after they learned their draft numbers. As predicted, those with draft numbers such that there was no risk of being drafted (who therefore were engaged in dull tasks with no extrinsic rewards) showed improved attitudes about ROTC and even slightly enhanced performance. Staw (1977) summarizes several experiments that suggest limits to the applicability of the oversufficientjustification hypothesis, such as that there should be no pre-existing norm for payment. These 
limits suggest that the oversufficient-justification effect will be unlikely to be central in employment relationships, but might be important in voluntary organizations or with reference to tasks in an employment relationship that are usually performed voluntarily.

Another prominent aspect of social psychology that bears on employment relationships is social comparison theory (Vroom, 1968; Goodman, 1977). O'Reilly, Main, and Crystal (1988) apply this theory CEO pay; Frank (1985) studies other economic applications. After controlling for firm performance, sales, size, and industry effects (at something between the 1- and 2-digit level), O'Reilly, Main, and Crystal find that CEO pay is significantly related to the average salary of the outside directors (in their main jobs) and even more strongly related to the average salary of the outside directors on the compensation committee. I would like to see this finding replicated on richer cross-section data with finer industry controls, and on panel data with changes in board composition. More generally, I think such findings from other fields should be pursued rather than dismissed. ${ }^{10}$

The issue of social comparison leads naturally to the issue of groups-another arena in which economic thinking often diverges from social-psychological and sociological views. Recent economic research on the effects of group incentive plans documents non-trivial productivity increases, such as Kruse (1993) on profit sharing and Jones and Kato (1995) on employee stock-ownership plans. To an economist, these results raise the question of free-riding: how do group incentive plans solve the so-called 1/N problem (Alchian and Demsetz, 1972; Holmstrom, 1982a)? Social psychologists and sociologists, however, have long emphasized the importance of informal norms in influencing behavior in groups.

Some arguments involving norms have the "over-socialized" character (i.e., norms so strong that no room remains for individual choice) that economists have found troubling, but subtler arguments are also available. Granovetter (1985:486), for example, argues that "culture is not a once-for-all influence but an ongoing process, continuously constructed and reconstructed during interaction. It not only shapes its members but also is shaped by them, in part for their own strategic reasons." Tirole's (1996) analysis of corruption has something of this flavor; similar analyses of useful rather than destructive cultures should also be possible.

Economists have just begun to think about groups in organizations, but even the seemingly small step of adding a third actor to the classic agency model (i.e., a supervisor, as well as a principal and an agent) opens new horizons, as Tirole (1986) showed in his seminal analysis of collusion. All three actors in Tirole's model have the conventional preferences for actors in an economic model. More recently, other theorists have begun to explore preferences

10 Hallock (1995) studies a related issue: reciprocity via interlocking directorates (i.e., the CEO of firm A is a director of firm B, and vice versa). Hallock finds that, after controlling for firm characteristics, interlocking directorates are associated with no more than 10 percent higher pay. 
drawn from the social psychology and sociology literatures: see Kandel and Lazear (1992) and Barron and Gjerde (forthcoming) on peer pressure and Rotemberg (1994) on altruism in the workplace. Gaynor and Rebitzer (1995) deserve special recognition for not only developing a model involving group norms but also trying to test it!

\section{Careers in Organizations}

Virtually all of the foregoing theory and evidence on incentive pay was cast as occurring within a firm, but much of it could just as well have been cast as between firms. In this section I step more resolutely inside the firm, by focusing on careers in organizations. Most of the evidence I report concerns white-collar workers, especially managerial and professional workers. Most of the work settings that generated the data are similar to the idealized employment system Osterman (1987) calls "salaried" (as opposed to "industrial," "craft," or "secondary").

I will treat jobs as defined in advance, independent of the people who fill them. This assumption may seem unremarkable, but some firms have no jobs of this kind (Kaftan and Barnes, 1991) and some firms with many highly formalized jobs nonetheless have an important minority of jobs that do not fit this description (Miner, 1987). I will also largely treat jobs as defined for individuals, rather than for teams, in spite of the recent surge of interest in the latter (e.g., Katzenbach and Smith, 1993).

One might think that, having sidestepped these fashionable issues in job design, I would be reduced to discussing a mature body of theory and evidence focused on a somewhat outdated definition of a job. Unfortunately, the situation is not that good. Instead, I see this section, like the second half of the first section, as an attempt to survey an emerging literature- this time on jobs, and how they are strung into careers in organizations. I begin with evidence, then turn to theory, and finally suggest some new dimensions.

\section{A. Evidence}

In this sub-section I describe a wide range of findings concerning wages, promotions, and performance evaluations inside firms. I attempt to assess which findings are true in a variety of environments and which may be limited to narrower settings such as a particular firm, industry, or occupation. Most of the evidence I present concerns white-collar, salaried workers employed by large US firms. Nonetheless, the literature is large and varied. I therefore consider only four categories of evidence: positions, wages, the interplay between positions and wages, and performance evaluation. Even in a fairly narrow category such as positions, however, it is difficult to compare and evaluate some of the findings. Different authors have asked different questions of seemingly comparable datasets. It would be very helpful if authors of future studies 
would address a common core of questions before turning to specific issues of their own interest. Indeed, the same could be said of the existing studies: it would be very helpful if these authors would return to their data to address remaining core questions. To prompt discussion, I propose a set of such core questions at the end of this sub-section.

1) Positions: The first, simple finding is that demotions are rare. This is intuitive but rarely documented, in part because defining a demotion requires that jobs be ordered. One way to order jobs is by ranking their wages (Lazear, 1992); another is via patterns in observed job transitions (Baker, Gibbs, and Holmstrom, 1994a); a third is to ask whether formal job ladders exist (Baron, Davis-Blake, and Bielby, 1986) and are used (DiPrete, 1987). Relatively few studies produce job orderings; as far as I know, only Baker, Gibbs, and Holmstrom (hereafter $\mathrm{BGH}$ ) document the unsurprising fact that demotions are rare.

Much more attention has been paid to promotions (which again require jobs to be ordered by some method). In particular, serial correlation in promotion rates (i.e., a "fast track") has been studied extensively (Rosenbaum, 1984; Brüderl, Diekmann, and Preisendörfer, 1991; BGH, 1994a; Spilerman and Petersen, 1993; Spilerman and Ishida, 1994; and Podolny and Baron, 1995). There has also been some analysis of the hazard rate for job-to-job transitions within a firm (Felmlee, 1982; Althauser and Kalleberg, 1990; and Lazear, 1992). This work varies in its sensitivity to issues such as competing risks (e.g., promotion versus exit, or up versus across job ladders) and unobserved heterogeneity. It also varies in its conclusions: Felmlee and Althauser-Kalleberg find positive duration dependence (i.e., an increasing escape rate to another job in the firm as time on the current job increases), whereas Lazear finds negative.

The natural extension of work on fast tracks and hazard rates is to analyze more detailed information from the history of a worker's job assignments within a firm, such as the following analysis by Chiappori, Salanié, and Valentin (1996). Consider two workers who begin in level 1 at date 1 and are both in level 2 at date 3. Suppose worker $A$ was promoted between dates 1 and 2 , whereas worker $\mathrm{B}$ was promoted between dates 2 and 3 . One can ask which worker fares better after date 3. As predicted by a learning model akin to Harris and Holmstrom (1982), Chiappori et. al. find that worker B fares better after date 3.11

2) Wages: Using administrative records to study salaried managers during their careers at a single firm, BGH (1994b) find that nominal wage cuts are extremely rare (200 observations out of more than 60,000 ), but that zero nominal increases are not. It would be interesting to use large

11 At first blush, this finding may seem inconsistent with the existence of a fast track. The Chiappori et. al. finding could be compatible with a fast track, however, because some fast-trackers may not be eligible for the sample constructed by Chiappori et. al.: workers A and B are at level 2 at date 3, but a true fast-tracker may already 
panel datasets to study the generality of these findings across firms, but such efforts must confront several issues. First, for non-salaried workers, fluctuations in hours (e.g., via overtime) would change eamings even if wages were constant. Second, there may be substantial measurement error in earnings or wages. Third, there may be measurement error in firm affiliation, clouding the question of who stayed with the firm.

Card and Hyslop (1995) confront these issues using data from the Current Population Survey (CPS) and the Panel Study of Income Dynamics (PSID) covering hourly workers who stayed with their employer for two consecutive interview dates. Card and Hyslop's findings are qualitatively similar to BGH's: nominal wage cuts are rare (but not as rare as in BGH), but zero nominal increases are not (indeed, they form a prominent spike in the distribution). Kahn (1994) presents similar evidence. Card and Hyslop, Kahn, BGH (1994b), and McLaughlin (1994) all find that real wage cuts are not rare.

Taking a cue from the large literature on fast tracks, BGH (1994b) ask the analogous question about wages: is there serial correlation in wage changes? They find that the correlation between $\Delta \mathrm{w}_{\mathrm{t}}\left(=\mathrm{w}_{\mathrm{t}}-\mathrm{w}_{\mathrm{t}-1}\right)$ and $\Delta \mathrm{w}_{\mathrm{t}-1}$ is .30 , and between $\Delta \mathrm{w}_{\mathrm{t}}$ and $\Delta \mathrm{w}_{\mathrm{t}-2}$ is .25. Of course, this finding could reflect concave effects of experience and/or tenure, so BGH compute the analogous correlations for changes in wage residuals rather than in wages. These correlations are indeed smaller: .17 and .12 , respectively.

As with wage cuts, there has been some analysis of the serial correlation of wage changes (and changes in wage residuals) using large panel datasets. Using data on American scientists, Lillard and Weiss (1979) find statistically significant person effects in both the level and the growth of earnings residuals, as well as a significant correlation between the two. Similarly, Hause (1980) finds significant person effects in the growth of eamings among young Swedish males. Abowd and Card (1989), however, analyze three larger and more heterogeneous datasets (the PSID, the National Longitudinal Survey, and the Seattle/Denver Income Maintenance Experiment) and cannot reject a statistical model that has no person effect in the growth rate of (experience-adjusted) earnings.

Workers in the Lillard-Weiss, Hause, and Abowd-Card samples did not necessarily remain with a single employer, as was the case in BGH, but Topel (1991) and Topel and Ward (1992) study within-firm wage growth. Both papers find that within-firm changes in wage residuals are serially uncorrelated, using data from the PSID and Social Security earnings records, respectively. Topel and Ward also find, however, that prior wage growth affects job

have been promoted to level 3 by this date. This is one example of how it would be useful for past, present, and future authors to address a core set of questions before turning to issues specific to their paper. 
mobility, even after controlling for the current wage-a finding that would be easily explained by person effects in wage growth.

In sum, three small, relatively homogeneous samples (BGH, Lillard-Weiss, and Hause) find evidence of a person effect in the growth rate of earnings, whereas five large, heterogeneous samples (three from Abowd-Card, one (related) from Topel, and one from Topel-Ward) do not. This welter of findings deserves further attention. One possible explanation is that only certain small groups of workers (such as the managerial and professional workers in BGH and LillardWeiss) exhibit such a person effect. If most groups of workers do not exhibit this effect then the representative cross-sections in Abowd-Card, Topel, and Topel-Ward would not either.

Finally, BGH (1994b) find that a difference in the starting wages of two cohorts persists as the cohorts age. Put differently, raises for workers already in the firm are highly correlated, regardless of cohort, so much of the wage difference between two cohorts comes from the difference in their starting wages. This finding is reminiscent of Doeringer and Piore's (1971) description of how an internal labor market buffers workers from the vagaries of the external market, and of Beaudry and DiNardo's (1991) evidence on the effect of previous unemployment rates on current wages (although Beaudry and DiNardo find that the lowest unemployment rate since being hired has the largest effect, rather than the unemployment rate at the date hired).

3) Positions and Wages: Just as the first, simple finding on positions was that demotions are rare, the first, simple finding on wages and positions is that the wage increase upon promotion is larger than for those not promoted. For example, in a study of 461 top executives in 72 large US manufacturing firms from 1964 to 1981, Murphy (1985) found that the average real increase in salary plus bonus for the whole sample was $3.7 \%$ but the average increase for a Vice President promoted to President was $20.9 \%$, and for a President promoted to CEO $14.3 \%$. On the other hand, the wage change at promotion can be small compared to the difference in average wages between the two levels. For example, Murphy found that the average salary plus bonus for Presidents was $60 \%$ higher than for Vice Presidents (but only 13\% higher for CEOs than for Presidents). BGH (1994b) replicate these results for lower-level managers in one firm: wage increases upon promotion are larger than for those not promoted, but smaller than the difference in average wages between the two levels.

In keeping with the findings of serial correlation in promotion rates and in wage changes, BGH (1994b) find that wage increases forecast promotions. That is, among all the workers just promoted to level $n$, the next raise is lower for those who subsequently wait longer to be promoted to level $n+1$.

BGH (1994a) find that promotions come disproportionately from the upper deciles of the wage distribution for the lower job, but not exclusively: some promotions come from each decile. Similarly, some promotions go into each decile of the wage distribution for the upper job, 
although most go into the lower deciles. At higher job levels, a larger fraction of promotions come from the upper deciles of the lower job and go into the lower deciles of the upper job.

Murphy (1991) describes the official schedule of wage-increase ranges at Merck \& Co.: controlling for performance evaluation, wage increases are smaller for those who begin in higher quartiles of the wage distribution of a given job level. BGH (1994a) replicate and extend this finding: in the firm they study, the fact holds for those who are not promoted, for those who are, and for the sample as a whole.

4) Performance Evaluations: Much of what we know about the relationship between wages and performance evaluations is drawn from two influential papers by Medoff and Abraham (1980, 1981). They study managerial and professional workers in three firms and report three basic facts: wages increase with seniority; wages increase with performance evaluation; and the effect of seniority on wages is essentially independent of the presence of controls for performance evaluation. An implication of these three facts (bome out in their data) is that performance evaluation is essentially independent of seniority. All of this might cause one to question the role of performance evaluation, but Medoff and Abraham find that increases in performance evaluation predict raises and promotions. Gibbs (1995) presents similar evidence on the effects of performance evaluations in the firm studied by Baker, Gibbs, and Holmstrom (1994a,b).

Waldman and Avolio (1986) conduct a meta-analysis of 40 samples, largely from the literature in industrial psychology. Waldman and Avolio find that productivity increases with age but performance evaluation is essentially flat with age. Replacing "productivity" with "wage" and "age" with "seniority" makes the two Waldman-Avolio findings identical to two of the MedoffAbraham findings.

5) Summary: There is a large and diverse set of findings concerning wage and promotion dynamics within firms. Some of the findings have so far been documented only in individual firms, but I have attempted to report evidence from large panel datasets whenever possible. It would be a great service if empirical researchers would provide evidence on a core set of questions before studying specific issues of their own. Among these core questions might be: (1) is there a fast track?, (2) are nominal wage cuts rare?, (3) are changes in wage residuals serially correlated?, (4) are there cohort effects in wages?, (5) are wage increases upon promotion large compared to normal wage changes but small compared to the difference in average wages between the two levels?, (6) do wage increases forecast promotions?, (7) do promotions come from and go to all the deciles of the wage distributions for the lower and upper levels?, (8) are wage increases smaller for those who begin in higher quartiles of the wage distribution for that level?, (9) do wages increase and are promotions more likely with higher performance evaluations (both in cross-section and in time-series)?, and (10) is the effect of seniority on 
wages independent of the presence of controls for performance evaluation? Theoretical researchers, for their part, could advance the literature by developing models that address broad patterns of facts, abandoning the more common strategy of developing a model to explain one or a few findings in isolation.

\section{B. Towards a Theory}

There are at least four potential building blocks for a theory of wage and promotion dynamics within firms: task assignment, toumaments, on-the-job human-capital acquisition, and learning. Each of these building blocks has received some development in the literature, but many of the resulting models were designed to explain at most a few stylized facts. I will therefore briefly describe some of the major contributions to these four literatures, indicating some of the facts each was designed to explain. I will then argue, however, that future theorizing should aim at explaining broad pattems of evidence rather than a fact or two, and I will give examples of recent theorizing in this vein.

1) Task Assignment: The task-assignment literature begins with static, full-information models (Sattinger, 1975; Rosen, 1982; Waldman, 1984a) that offer an explanation for skewness in the wage distribution; see Sattinger (1993) for a review. A new line of research emphasizes that the firm's decision to assign a worker to a new task signals information to prospective employers about the worker's productive ability (Waldman, 1984b; Ricart i Costa, 1988; Bernhardt and Scoones, 1993). This signaling effect offers an explanation for the large wage increase upon promotion. Because prospective employers bid up the wage of promoted workers, however, the current employer chooses an inefficiently tough promotion criterion: workers who would be marginally more productive in the new job are not enough more productive to compensate for the wage increase.

2) Tournaments: The tournaments literature begins with the classic analysis by Lazear and Rosen (1981) that offers an explanation for large wage increases upon promotion. Rosen's (1986) sequential-elimination model shows that a big prize at the end (such as promotion to CEO) has important effects on incentives in the early rounds, so the distribution of prizes can be quite convex and yet create constant incentives across rounds. Meyer (1992) shows that in a sequence of (non-elimination) tournaments it is efficient to introduce second-round bias in favor of the first-round winner. (A small second-round bias causes a second-order reduction in second-round effort but a first-order increase in first-round effort.) Thus, a fast track can emerge from an optimal incentive scheme.

3) Human Capital: From the perspective of careers in organizations, the human-capital literature moves from Becker (1962) to Hashimoto (1981) to Carmichael (1983). Becker suggested that the firm and the worker will share both the costs and the benefits of investments in 
specific capital. Hashimoto emphasized that such sharing would not be necessary if the firm and the worker did not have private information about post-investment match quality. In the presence of such private information, however, the optimal sharing rule produces inefficient turnover. Carmichael made the first explicit reference to careers in organizations by showing that a promotion ladder (i.e., wages attached to jobs, with jobs assigned by seniority) can induce investment and produce efficient turnover.

More recently, Kahn and Huberman (1988), Waldman (1990), and Prendergast (1993) built on Carmichael's insight to analyze promotion and up-or-out rules. Others have reinvestigated the Becker-Hashimoto sharing model. Chang and Wang (1996), for example, derive a host of new results, including underinvestment in general human capital, in the (plausible) case in which human-capital investments cannot be observed by prospective employers. And Prendergast (1989), Acemoglu and Pischke (1996), and Chang and Wang (1995) show that the interaction of investment and turnover can create multiple equilibria: if almost no one will be laid off then it is efficient to invest, so almost no one is laid off, and vice versa.

4) Learning: I organize the literature on learning about workers into four categories: passive response, active experimentation, commitment problems, and strategic information transmission. Jovanovic (1979) and MacDonald (1982) are classic examples from the passiveresponse category-information (say, about a worker's productivity) arrives and the firm responds optimally (say, by changing the worker's wage). Murphy (1986) develops two models-one emphasizing passive learning, the other incentives-and tests their distinctive predictions. Murphy's evidence is inconclusive, perhaps because both models are actually at work in the data, but his paper is noteworthy for its attempt to distinguish between competing reasons why pay might be linked to performance. O'Flaherty and Siow $(1992,1995)$ use a passive-learning model to study up-or-out rules.

Meyer (1991) falls in the active-experimentation category: in a sequence of contests (similar to Meyer (1992), described above, but with learning about worker ability rather than moral hazard), the firm finds it optimal to bias the second round in favor of the first-round winner. (Without a second-round bias either the first-round winner wins the second round, merely confirming the first-round information, or the first-round loser wins, canceling out the first-round information.) Thus, as in Meyer (1992), a firm may find it optimal to create a fast track.

Harris and Holmstrom (1982) show how learning can cause commitment problems. A risk-neutral firm would like to guarantee a risk-averse worker a constant wage, but information about the worker's performance may cause prospective employers to bid up the worker's wage. If the current employer cannot bind the worker to the firm then only those workers with poor 
performances will be left working at the guaranteed wage. Consequently, the firm can offer only limited insurance (in the form of a guaranteed wage) and must collect a premium for it up front (in the form of a wage below expected productivity during the time before performance information arrives).

Finally, Greenwald (1986), Lazear (1986b), and the signaling papers noted above in the task-assignment literature analyze strategic information transmission. Greenwald studies the winner's curse that afflicts a prospective employer when making an offer; Lazear considers the possibility that the prospective employer may have superior information, in which case workers who never get offers are stigmatized. Gibbons and Katz (1991) develop a similar model of layoffs and present evidence consistent with the model: for white-collar workers (who are less likely to be subject to inverse-seniority layoff rules), the re-employment wages of laid-off workers are lower than those of observationally equivalent workers displaced in plant closings, consistent with a layoff being a bad signal about the worker's ability.

5) Beyond building blocks: These four literatures—task assignment, tournaments, human capital, and learning - have developed some important theory and met with some empirical success. In the last few years, however, a new style of theory on career dynamics has begun to emerge, in which models speak to broad patterns of facts rather than one or a few in isolation. Harris and Holmstrom (1982), MacLeod and Malcomson (1988), Demougin and Siow (1994) and Bernhardt (1995) are contributions in this vein. I will briefly describe Gibbons and Waldman (1996), because it makes the broadest attempt to relate to a detailed pattern of facts about careers in organizations.

Waldman and I develop a model that blends task assignment, on-the-job human capital acquisition, and learning. The predictions of the model are consistent with much of the evidence on positions, wages, and positions and wages described in the previous sub-section, including: (1) both demotions and (real) wage decreases will be rare, although demotions will be much more rare; (2) on average, workers who receive large wage increases early in their stay at one level of a job ladder will be promoted more quickly to the next level; (3) promotions will be associated with large wage increases, but these wage increases will be small relative to the difference between average wages across the relevant job levels; (4) there will be significant serial correlation in both wage increases and promotion rates; and (5) individuals promoted from one job level to the next will come disproportionately (but not exclusively) from the top of the lower job's wage distribution and will arrive disproportionately (but not exclusively) towards the bottom of the higher job's wage distribution. Furthermore, the model is also consistent with the fourth category of evidence, on performance evaluations.

The main elements of the model are simple. A worker with innate ability $\theta$ and labormarket experience $\mathrm{x}$ has productive ability $\eta(\theta, \mathrm{x})$. A worker's innate ability can be either high or 
low; experience improves a worker's productivity through learning by doing. There are three jobs, which differ in their sensitivity to productive ability. Under full information, workers with high values of $\eta$ would be assigned to the top job, workers with intermediate values of $\eta$ to the middle job, and workers with low values of $\eta$ to the bottom job. With imperfect information about innate ability, workers are assigned to jobs based on their expected productive abilities and paid their expected outputs in their assigned jobs.

In each period, a worker's output provides a noisy signal about his or her productive ability. Because labor-market experience is observable, the signal about productive ability can be translated into a signal about innate ability. Growth in productive ability with experience implies that, on average, workers progress up the job ladder, receiving wage increases every period and promotions every so often. But leaming about innate ability implies that wage cuts sometimes occur; indeed, demotions, while rare, are possible. Serial correlation in promotion rates and wage increases follow from the differences in innate ability, as does the finding that wage increases forecast promotion. Large wage increases at promotion follow in part from a selection effect: those who get promoted in a given period are disproportionately those who received good news about their abilities. Finally, the findings on performance evaluations follow if it is innate ability $(\theta)$ rather than productive ability $(\eta)$ or realized output that is evaluated; that is, evaluators adjust realized output for the skill acquired with experience.

The Gibbons-Waldman model (and others like it) address broad patterns of facts about careers in organizations. Nonetheless, each existing model fails to produce some of the existing facts. There are four main facts that do not emerge from the Gibbons-Waldman model: nominal wage cuts are rare (but see MacLeod and Malcomson (1993) for a theory of nominal rigidity), wage differences between cohorts are primarily a function of differences in their starting wages, wage increases are smaller for those who begin in higher quartiles, and wage distributions for different job levels overlap (although this last fact could be due to excessively coarse job definitions in some datasets). Of course, some of these existing "facts" have not yet been established beyond a single firm, hence my appeal for systematic empirical analysis of core questions.

\section{New Dimensions}

Sociologists have long explored the effects of aggregate-level variables such as vacancy chains, social networks, and organizational demography on individual-level outcomes such as attainment and turnover. It would be interesting to consider whether the theoretical or econometric tools of labor economics can shed any new light on the sociologists' preferred interpretations of these effects. 
White (1970), for example, introduced and explored the consequences of vacancy chains: if worker A gets promoted from job 2 to job 3, it creates an opportunity for worker B to be promoted from job 1 to job 2. The basic idea is not startling, but it is sensible; see Stewman (1986) for elaborations. Demougin and Siow (1994) and Rebitzer and Taylor (1995) have made nice starts towards incorporating such demand-side effects into theoretical models in labor economics.

Granovetter (1974) analyzed the importance of friends and relatives as sources of information for job-seekers. More recently, Burt (1992) and Podolny and Baron (1995) have studied analogous networks within firms, asking how the size and interconnectedness of an individual's network influences the individual's promotion prospects. Burt gives special prominence to the idea of a "structural hole," where worker A knows several workers of type B and several of type $\mathrm{C}$, but no $\mathrm{B}$ worker knows a $\mathrm{C}$ worker. The existing sociological research largely treats networks as exogenous and asks what they do. This approach has already migrated into the economics literature; see Montgomery (1991), for example. But if certain network forms are advantageous, such as Burt's structural hole, then it would be interesting to consider under what circumstances such networks might be formed or modified endogenously.

Finally, Pfeffer (1983) pioneered the study of "organizational demography" by suggesting how the distributions of individual attributes (such as age, sex, race, education level, and seniority) within an organization or work group might influence outcomes such as innovation, productivity, satisfaction, and turnover. A large empirical literature now exists. Wagner, Pfeffer, and O'Reilly (1984), for example, study turnover in 599 top-management groups in 31 Fortune 500 firms. In a logistic regression on individual turnover, including controls for the individual's age and the firm's performance, the extent to which the individual is similar in age to other group members decreases the chance of turnover.

\section{Conclusion}

I hope to have shown that labor economics has made some progress towards understanding two limited aspects of employment relationships: incentive pay and careers in organizations. Several other concrete questions also deserve attention, including job design, skill development, and participative decision-making. A more fundamental and abstract question also needs work: what is an employment relationship? The classic papers by Simon (1951) and Williamson, Wachter, and Harris (1975) provide good starts. An ideal answer to this fundamental question would also shed light on some of the concrete issues-incentives, job design, and the like. 
Much of the theory and evidence I have described is geared towards white-collar workers (especially managers and professionals) in large US firms. That is, I have focused on Osterman's (1987) "salaried" employment system, rather than the "industrial," "craft," or "secondary" employment systems. All four systems deserve more attention, as do systems (and their institutions) in other countries and from other eras.

One view is that economics is about markets, so labor economics should focus on the labor market, leaving the study of what goes on inside firms to fields such as human resource management, industrial relations, organizational psychology, and organizational sociology. Obviously, I disagree: I think labor economics has too many theoretical and empirical tools at its disposal to make such an allocation of attention socially optimal. At the same time, I hope to have suggested several areas in which labor economics could benefit from an exchange of theory and evidence with the many other fields that study employment relationships.

\section{References}

Abowd, John. 1990. "Does Performance-Based Managerial Compensation Affect Corporate Performance?" Industrial and Labor Relations Review 43: 52S-73S.

and David Card. 1989. "On the Covariance Structure of Earnings and Hours Changes." Econometrica 57:411-45.

Francis Kramarz, and David Margolis. 1994. "High Wage Workers and High Wage Firms." National Bureau of Economic Research Working Paper \#4917.

Acemoglu, Daron and Jörn-Steffen Pischke. 1996. "Why Do Firms Train? Theory and Evidence." NBER Working Paper \#5605.

Alchian, Armen and Harold Demsetz. 1972. "Production, Information Costs, and Economic Organization." American Economic Review 62:777-95.

Alston, Lee. 1981. "Tenure Choice in Southern Agriculture, 1930-1960." Explorations in Economic History 18:211-32.

and Robert Higgs. 1982. "Contractual Mix in Southern Agriculture since the Civil War: Facts, Hypotheses, and Test." Journal of Economic History 42:327-53.

Althauser, Robert and Ame Kalleberg. 1990. "Identifying Career Lines and Internal Labor Markets Within Firms: A Study in the Interrelationships of Theory and Methods." In R. Breiger (ed.), Social Mobility and Social Structure. Cambridge: Cambridge University Press.

Anderson, Kathryn, Richard Burkhauser, and Jennie Raymond. 1993. "The Effect of Creaming on Placement Rates under the Job Training Partnership Act." Industrial and Labor Relations Review 46:613-24.

Antle, Rick and Abbie Smith. 1986. "An Empirical Investigation of the Relative Performance Evaluation of Corporate Executives." Journal of Accounting Research 24:1-39. 
Asch, Beth. 1990. "Do Incentives Matter? The Case of Navy Recruiters." Industrial and Labor Relations Review 43:89-106.

Baker, George. 1992. "Incentive Contracts and Performance Measurement." Journal of Political Economy 100:598-614.

Robert Gibbons, and Kevin J. Murphy. 1994. "Subjective Performance Measures in Optimal Incentive Contracts." Quarterly Journal of Economics 109:1125-56.

, and . 1996. "Implicit Contracts and the Theory of the Firm.", Unpublished manuscript, Cornell University.

Michael Gibbs, and Bengt Holmstrom. 1994a. "The Internal Economics of the Firm: Evidence from Personnel Data." Quarterly Journal of Economics 109:881-919.

Journal of Economics 109:921-55

1994b. "The Wage Policy of a Firm." Quarterly

Baron, Jarnes. 1988. "The employment relation as a social relation." Journal of the Japanese and International Economies 2:492-525.

Alison Davis-Blake, and William Bielby. 1986. "The Structure of Opportunity: How Promotion Ladders Vary within and among Organizations." Administrative Science Quarterly 31:248-73.

Barron, John and Kathy Paulson Gjerde. "Peer Pressure in an Agency Relationship." Forthcoming, Journal of Labor Economics.

Beaudry, Paul and John DiNardo. 1991. "The Effect of Implicit Contracts on the Movement of Wages over the Business Cycle: Evidence from Microdata." Journal of Political Economy 99:665-88.

Becker, Gary. 1962. Human Capital. New York: Columbia University Press.

Bernhardt, Dan. 1995. "Strategic Promotion and Compensation." Review of Economic Studies 62:315-39.

and David Scoones. 1993. "Promotion, Turnover, and Preemptive Wage Offers." American Economic Review 84:771-91.

Brickley, James, Sanjai Bhagat, and Ronald Lease. 1985. "The Impact of Long-Range Managerial Compensation Plans on Shareholder Wealth." Journal of Accounting and Economics 7:115-30.

Brown, Charles. 1990. "Firm's Choice of Method of Pay." Industrial and Labor Relations Review 43:165S-182S.

1992. "Wage Levels and Methods of Pay." Rand Journal of Economics 23:36675 .

Brüderl, Josef, Andreas Diekmann, and Peter Preisendörfer. 1991. "Patterns of Intraorganizational Mobility: Tournament Models, Path Dependency, and Early Promotion Effects." Social Science Research 20:197-216.

Bull, Clive. 1987. "The Existence of Self-Enforcing Implicit Contracts," Quarterly Journal of Economics 102:147-59.

Burt, Ronald. 1992. Structural Holes: The Social Structure of Competition. Cambridge: Harvard University Press. 
Burtis, Andrew and John Gabarro. 1995. "Brainard, Bennis \& Farrell." Harvard Business School Case \#9-485-037.

Card, David and Dean Hyslop. 1995. "Does Inflation 'Grease the Wheels of the Labor Market'?" Princeton University Industrial Relations Section Working Paper \#356, December.

Cappelli, Peter and Keith Chauvin. 1991. "An Interplant Test of the Efficiency Wage Hypothesis." Quarterly Journal of Economics 106:769-87.

Carmichael, Lome. 1983. "Firm-specific human capital and promotion ladders." Bell Journal of Economics 14:251-58.

and Bentley MacLeod. 1993. "Worker Cooperation and the Ratchet Effect." Unpublished manuscript, Queen's University.

Chang, Chun, and Yijiang Wang. 1995. "A Framework for Understanding Differences in Labor Turnover and Human Capital Investment." Journal of Economic Behavior and Organization 28:91-105.

Chang, Chun, and Yijiang Wang. 1996. "Human Capital Investment under Asymmetric Information: The Pigovian Conjecture Revisited." Forthcoming, Journal of Labor Economics 14:505-19.

Chiappori, Pierre-André, Bernard Salanié, and J. Valentin. 1996. "Insurance, Learning, and Career Profiles: An Empirical Test.” INSEE (CREST) Working Paper \#9623.

Chevalier, Judith and Glen Ellison. 1995. "Risk Taking by Mutual Funds as a Response to Incentives." NBER Working Paper \#5234, August.

Clawson, Daniel. 1980. Bureaucracy and the Labor Process. New York: Monthly Review Press, 1980.

Cragg, Michael. 1995. "Performance Incentives in Government Subcontracting: Evidence from the Job Training Partnership Act (JTPA)." Unpublished manuscript, Columbia University.

Demougin, Dominique and Aloysius Siow. 1994. "Careers in Ongoing Hierarchies." American Economic Review 84:1261-77.

DiPrete, Thomas. 1987. "Horizontal and Vertical Mobility in Organizations." Administrative Science Quarterly 32:422-44.

Doeringer, Peter and Michael Piore. 1971. Internal Labor Markets and Manpower Analysis. Lexington, MA: Heath Lexington Books.

Dye, Ronald. 1992. "Relative Performance Evaluation and Project Selection." Journal of Accounting Research 30:27-52.

Eccles, Robert and Dwight Crane. 1988. Doing Deals: Investment Banks at Work. Boston: Harvard Business School Press.

Ehrenberg, Ronald and Michael Bognanno. 1990. "Do Toumaments Have Incentive Effects?" Journal of Political Economy 98:1307-24.

Fama, Eugene. 1980. "Agency Problems and the Theory of the Firm." Journal of Political Economy 88:288-307.

Fast, Norman and Norman Berg. 1975. "The Lincoln Electric Company." Harvard Business School Case \#376-028. 
Felmlee, Diane. 1982. “Women's Job Mobility Processes." American Sociological Review 47:142-51.

Frank, Robert. 1985. Choosing the Right Pond: Human Behavior and the Quest for Status. New York: Oxford University Press.

Garen, John. 1994. "Executive Compensation and Principal-Agent Theory." Journal of Political Economy. 102:1175-99.

Gaynor, Martin and Paul Gertler. 1995. "Moral hazard and risk spreading in partnerships." Rand Journal of Economics 26:591-613.

and James Rebitzer. 1995. "Equity and Effort: A Study of Group Norms and Incentives in Pay Systems." Unpublished manuscript, Camegie Mellon University.

Gibbons, Robert. 1987. "Piece-Rate Incentive Schemes." Journal of Labor Economics 5:41329. 9:351-80.

and Lawrence Katz. 1991. "Layoffs and Lemons." Journal of Labor Economics and Kevin J. Murphy. 1990. "Relative Performance Evaluation for Chief Executive Officers." Industrial and Labor Relations Review 43: 30S-51S.

and 1992. "Optimal Incentive Contracts in the Presence of Career Concerns: Theory and Evidence."Journal of Political Economy 100:468-505.

and Michael Waldman. 1996. "A Theory of Wage and Promotion Dynamics Inside a Firm." Unpublished manuscript, Cornell University.

Gibbs, Michael. 1995. "Incentive compensation in a corporate hierarchy." Journal of Accounting and Economics 19:247-77.

Goldin, Claudia. 1986. "Monitoring Costs and Occupational Segregation by Sex: A Historical Analysis." Journal of Labor Economics 4:1-27.

Gompers, Paul and Josh Lemer. 1994. "An Analysis of Compensation in the U.S. Venture Capital Partnership.” Unpublished manuscript, Harvard Business School.

Goodman, Paul. 1977. "Social Comparison Processes in Organizations." In B. Staw and G. Salancik (eds.), New Directions in Organizational Behavior.

Granovetter, Mark. 1974. Getting a Job: A Study of Contacts and Careers. Cambridge: Harvard University Press.

1985: "Economic Action and Social Structure: The Problem of Embeddedness." American Journal of Sociology 91:481-510.

Greene, Sarah and Leonard Schlesinger. 1992. "Gain Sharing at Star Cablevision Group." Harvard Business School Case \#9-692-012.

Greenwald, Bruce. 1986. "Adverse Selection in the Labor Market." Review of Economic Studies 53:325-47.

Hallock, Kevin. 1995. "Executive Pay and Reciprocally Interlocking Boards of Directors." Princeton University Industrial Relations Section Working Paper \#340.

Harris, Milton and Bengt Holmstrom. 1982. "A Theory of Wage Dynamics." Review of Economic Studies 49:315-33. 
Hashimoto, Masanori. 1981. "Firm-Specific Human Capital as a Shared Investment." American Economic Review 71:475-81.

Haubrich, Joseph. 1994. "Risk Aversion, Performance Pay, and the Principal-Agent Problem." Journal of Political Economy 102:258-76.

Hause, John. 1980. "The Fine Structure of Earnings and the On-the-Job Training Hypothesis." Econometrica 48:1013-30.

Healy, Paul. 1985. "The Effect of Bonus Schemes on Accounting Decisions," Journal of Accounting and Economics 7:85-107.

Higgs, Robert. 1973. "Race, Tenure, and Resource Allocation in Southern Agriculture, 1910." Journal of Economic History 33:149-69.

Holmstrom, Bengt. 1979. "Moral Hazard and Observability." Bell Journal of Economics 10:791.

1982a. "Moral Hazard in Teams." Bell Journal of Economics 13:324-40.

1982b. "Managerial Incentive Problems-A Dynamic Perspective." In Essays in Economics and Management in Honor of Lars Wahlbeck. Helsinki: Swedish School of Economics.

and Paul Milgrom. 1987. "Aggregation and Linearity in the Provision of Intertemporal Incentives." Econometrica, 55:303-328.

and

1991. "Multitask Principal-Agent Analyses: Incentive Contracts, Asset Ownership, and Job Design." Journal of Law, Economics, and Organization 7:2452.

Hutchens, Robert. 1987. “A Test of Lazear's Theory of Delayed Payment Contracts." Journal of Labor Economics 5:S153-S170.

Ichniowski, Casey, Kathryn Shaw, and Giovanna Prennushi. 1995. "The Effects of Human Resource Management Practices on Productivity." National Bureau of Economic Research Working Paper \#5333.

Itoh, Hideshi. 1992. "Cooperation in Hierarchical Organizations: An Incentive Perspective." Journal of Law, Economics, and Organization 8:321-45.

Janakiraman, Surya, Richard Lambert, and David Larcker. 1992. "An Empirical Investigation of the Relative Performance Evaluation Hypothesis." Journal of Accounting Research 30:53-69.

Jensen, Michael, and Kevin J. Murphy. 1990. "Performance Pay and Top-Management Incentives." Journal of Political Economy 98:225-64.

Jones, Derek and Takao Kato. 1995. "The Productivity Effects of Employee Stock-Ownership Plans and Bonuses: Evidence from Japanese Panel Data." American Economic Review 85:391-414.

Jovanovic, Boyan. 1979. "Job Matching and the Theory of Turnover." Journal of Political Economy 87:972-90.

Kaftan, Colleen and Louis Barnes. 1991. "Sun Hydraulics Corporation." Harvard Business School Case \#491-119. 
Kahn, Charles and Gur Huberman. 1988. "Two-sided Uncertainty and 'Up-or-Out' Contracts." Journal of Labor Economics. 6:423-44.

Kahn, Lawrence and Peter Sherer. 1990. "Contingent Pay and Managerial Performance." Industrial and Labor Relations Review 43: 107S-120S.

Kahn, Shulamit. 1994. "Evidence of Nominal Wage Stickiness from Microdata." Unpublished manuscript, Boston University.

Kandel, Eugene and Edward Lazear. 1992. "Peer Pressure and Partnership." Journal of Political Economy 100:801-17.

Kanemoto, Yoshitsugu and Bentley MacLeod. 1991. "The Ratchet Effect and the Market for Secondhand Workers." Journal of Labor Economics 10:85-98.

Katzenbach, Jon and Douglas Smith. 1993. The Wisdom of Teams: Creating the HighPerformance Organization. Boston: Harvard Business School Press.

Kerr, Steven. 1975. "On the Folly of Rewarding A, While Hoping for B." Academy of Management Journal 18:769-83.

Krueger, Alan. 1991. "Ownership, Agency, and Wages: An Examination of Franchising in the Fast Food Industry." Quarterly Journal of Economics 106:75-101.

Kruse, Douglas. 1993. Profit Sharing: Does It Make a Difference? Kalamazoo, MI: W.E. Upjohn Institute for Employment Research.

Lazear, Edward. 1979. "Why is there mandatory retirement?" Journal of Political Economy 87:1261-84.

. 1986a. "Salaries and Piece Rates." Journal of Business 59:405-431.

. 1986b. "Raids and Offer Matching." Research in Labor Economics 8:141-56.

97:561-80.

1989. "Pay Equality and Industrial Politics." Journal of Political Economy

1992. "The Job as a Concept." In W. Bruns (ed.), Performance Measurement, Evaluations, and Incentives. Boston: Harvard Business School Press.

1996. "Performance Pay and Productivity." Unpublished manuscript, Stanford University.

and Rosen, Sherwin. "Rank-Order Toumaments as Optimum Labor Contracts," Journal of Political Economy, 89 (October 1981): 841-864.

Lillard, Lee and Yoram Weiss. 1979. "Components of Variation in Panel Data: American Scientists 1960-1970." Econometrica 47:437-54.

MacDonald, Glenn. 1982. “A Market Equilibrium Theory of Job Assignment and Sequential Accumulation of Information." American Economic Review 72:1038-55.

MacLeod, W. Bentley and James Malcomson. 1988. "Reputation and Hierarchy in Dynamic Models of Employment." Journal of Political Economy 96: 832-854.

and

1989. "Implicit Contracts, Incentive Compatibility, and Involuntary Unemployment." Econometrica 57:447-80. 
and 1993. "Investments, Holdup, and the Form of Market Contracts." American Economic Review 83:811-37.

Maremont, Mark. 1995. "Blind Ambition: How the pursuit of results got out of hand at Bausch \& Lomb." Business Week, October 23.

Margolis, David. 1995. "Firm Heterogeneity and Worker Self-Selection Bias Estimated Returns to Seniority." CIRANO, University of Montreal, Working Paper \#95s-4.

Mathewson, Stanley. [1931] 1969. Restriction of Output Among Unorganized Workers. Carbondale, IL: Southern Illinois University Press.

McLaughlin, Kenneth. 1994. "Rigid Wages?” Journal of Monetary Economics 34:383-414.

Medoff, James, and Katharine Abraham. 1980. "Experience, Performance, and Earnings." Quarterly Journal of Economics 95:703-36.

and of Human Resources 16:186-216.

1981. “Are Those Paid More Really More Productive?" Journal

Meyer, Margaret. 1991. "Learning from Coarse Information: Biased Contests and Career Profiles." Review of Economic Studies 58:15-42.

1992. "Biased Contests and Moral Hazard: Implications for Career Profiles." Annales d'Economie et de Statistique 25/26:165-87.

Trond Olsen, and Gaute Torsvik. "Limited Intertemporal Commitment and Job Design." Forthcoming, Journal of Economic Behavior and Organization.

Milgrom, Paul and John Roberts. 1988. "An Economic Approach to Influence Activities in Organizations." American Journal of Sociology 94:S154-79.

Miner, Anne. 1987. "Idiosyncratic Jobs in Formalized Organizations." Administrative Science Quarterly 32:327-51.

Mirrlees, James. 1974. "Notes on Welfare Economics, Information, and Uncertainty." In M. Balch, D. McFadden, and S. Wu (eds.) Essays on Economic Behavior Under Uncertainty, Amsterdam: North-Holland.

Montgomery, James. 1991. "Social Networks and Labor-Market Outcomes: Toward an Economic Analysis." American Economic Review 81:1408-18.

Murphy, Kevin J. 1985. "Corporate Performance and Managerial Remuneration: An Empirical Analysis." Journal of Accounting and Economics 7:11-42.

- 1986. "Incentives, learning, and compensation: a theoretical and empirical investigation of managerial labor contracts." Rand Journal of Economics 17:59-76.

. 1991. “Merck \& Co., Inc. (A)." Harvard Business School Case \#9-491-005.

O'Flaherty, Brendan and Aloysius Siow. 1992. "On the Job Screening, Up or Out Rules, and Firm Growth." Canadian Journal of Economics 25:346-68.

and Labor Economics 13:709-35.

1995. "Up-or-Out Rules in the Market for Lawyers." Journal of

O'Reilly, Charles, Brian Main, and Graef Crystal. 1988. "CEO Compensation as Tournament and Social Comparison: A Tale of Two Theories." Administrative Science Quarterly 33: 257-74. 
Osterman, Paul. 1987. "Choice of Employment Systems in Internal Labor Markets." Industrial Relations 26:46-67.

. 1994. "How Common is Workplace Transformation and Who Adopts It?" Industrial and Labor Relations Review 47:173-88.

. 1995. "Skill, Training, and Work Organization in American Establishments." Industrial Relations 34:125-46.

Oyer, Paul. 1995. "The Effect of Sales Incentives on Business Seasonality." Princeton University Industrial Relations Section Working Paper \#354.

Patterson, Gregory. 1992. "Distressed Shoppers, Disaffected Workers Prompt Stores to Alter Sales Commission," Wall Street Journal, July 1.

Pencavel, John, and Ben Craig. 1994. "The Empirical Performance of Orthodox Models of the Firm: Conventional Firms and Worker Cooperatives." Journal of Political Economy 102:718-44.

Pfeffer, Jeffrey. 1983. "Organizational Demography." In L. Cummings and B. Staw (eds.), Research in Organizational Behavior. Greenwich, CT: JAI Press.

Podolny, Joel, and James Baron. 1995. "Resources and Relationships: Social Networks, Mobility, and Satisfaction in the Workplace." Unpublished manuscript, Stanford University.

Post, Richard J. and Kenneth E. Goodpaster. 1981. "H.J. Heinz Company: The Administration of Policy," Harvard Business School Case \#382-034.

Prendergast, Canice. 1989. Theories of Internal Labor Markets. Unpublished doctoral dissertation. Yale University.

1992. "Career Development and Specific Human Capital Collection." Journal of the Japanese and International Economies 6:207-27.

. 1993. "The Role of Promotion in Inducing Specific Human Capital Acquisition." Quarterly Journal of Economics 108:523-34. $13: 387-400$.

Rebitzer, James and Lowell Taylor. 1995. "When Knowledge is an Asset: Explaining the Organizational Structure of Large Law Firms." Unpublished manuscript, Camegie Mellon University.

Ricart i Costa, Joan. 1988. "Managerial Task Assignment and Promotions." Econometrica 56: 449-66.

Roberts, Johnnie L. 1989. "Credit Squeeze: Dun \& Bradstreet Faces Flap Over How It Sells Reports on Businesses," Wall Street Journal, March 2.

Rosen, Sherwin. 1982. "Authority, Control, and the Distribution of Earnings." Bell Journal of Economics 13:311-23.

1986. "Prizes and Incentives in Elimination Tournaments." American Economic Review 76:701-15.

Rosenbaum, James. 1984. Career mobility in a corporate hierarchy. New York: Academic Press. 
Rotemberg, Julio. 1994. "Human Relations in the Workplace." Journal of Political Economy 102:684-717.

Roy, Donald. 1952. "Quota Restriction and Goldbricking in a Machine Shop," American Joumal of Sociology 57:427-42.

Sattinger, Michael. 1975. "Comparative Advantage and the Distributions of Earnings and Abilities." Econometrica 43:455-68.

. 1993. "Assignment Models of the Distribution of Earnings." Journal of Economic Literature 31:831-80.

Shapiro, Carl and Joseph Stiglitz. 1984. "Equilibrium Unemployment as a Discipline Device." American Economic Review 74:433-44.

Simon, Herbert. 1951. "A Formal Model of the Employment Relationship." Econometrica 19:293-305.

Sloan, Richard. 1993. "Accounting eamings and top executive compensation." Journal of Accounting and Economics 16:55-100.

Spilerman, Seymour and Hiroshi Ishida. 1994. "Stratification and Attainment in Large Japanese Firms." Unpublished manuscript, Columbia University.

and Trond Petersen. 1993. "Organizational Structure, Determinants of Promotion, and Gender Differences in Attainment." Unpublished manuscript, Columbia University.

Staw, Barry. 1974. "Attitudinal and Behavioral Consequences of Changing a Major Organizational Reward: A Natural Field Experiment."Journal of Personality and Social Psychology 6:742-51.

1977. "Motivation in Organizations: Towards Synthesis and Redirection." In B. Staw and G. Salancik (eds.), New Directions in Organizational Behavior. Chicago: St. Clair Press.

Stewart, James. 1993. "Taking The Dare." The New Yorker, July 26, pp. 34-39.

Stewman, Shelby. 1986. "Demographic Models of Internal Labor Markets." Administrative Science Quarterly 31:212-47.

Tehranian, Hassan and James Waegelein. 1985. "Market Reaction to Short-Term Executive Compensation Plan Adoption." Journal of Accounting and Economics 7:131-44.

Tirole, Jean. 1986. "Hierarchies and Bureaucracies: On the Role of Collusion in Organizations." Journal of Law, Economics, and Organization 2:181-214.

. 1996. "A Theory of Collective Reputations (with applications to the persistence of corruption and firm quality)." Review of Economic Studies 63:1-22.

Topel, Robert. 1991. "Specific Capital, Mobility, and Wages: Wages Rise with Job Seniority, Journal of Political Economy 99:145-76.

and Michael Ward. 1992. "Job Mobility and the Careers of Young Men." Quarterly Journal of Economics 107:439-79.

Wagner, W. Gary, Jeffrey Pfeffer, and Charles O'Reilly. 1984. “Organizational Demography and Turnover in Top-Management Groups.” Administrative Science Quarterly 29:74-92. 
Waldman, David and Bruce Avolio. 1986. "A Meta-Analysis of Age Differences in Job Performance." Journal of Applied Psychology 71:33-38.

Waldman, Michael. 1984a. "Worker Allocation, Hierarchies, and the Wage Distribution." Review of Economic Studies 51:95-109.

. 1984b. "Job Assignment, Signaling, and Efficiency." RAND Journal of Economics 15:255-87.

1990. "Up-or-Out Contracts: A Signaling Perspective," Journal of Labor Economics 8: 230-50.

White, Harrison. 1970. Chains of Opportunity: System Models of Mobility in Organizations. Cambridge: Harvard University Press.

Williamson, Oliver. 1983. "Credible Commitments: Using Hostages to Support Exchange." American Economic Review 83:519-40.

Michael Wachter, and Jeffrey Harris. 1975. "Understanding the Employment Relation: the Analysis of Idiosyncratic Exchange." Bell Journal of Economics 6:250-78.

Vroom, Victor. 1968. "Industrial Social Psychology." In G. Lindzey and E. Aronson (eds.), The Handbook of Social Psychology. 